\title{
PENGEMBANGAN E-JOURNAL PARIWISATA POLITEKNIK DARUSSALAM MENGGUNAKAN OPEN JOURNAL SYSTEM
}

\author{
Yuniansyah $^{1^{*}}$, Andika Widyanto ${ }^{\prime}$ \\ $\left.1,2^{*}\right)$ Program Studi Sistem Informasi , STMIK PalComTech \\ Jalan Basuki Rahmat No.05 Palembang
}

\begin{abstract}
Abstrak - Penelitian ini bertujuan untuk mengembangkan Jurnal Pariwisata Darussalam berbasis jurnal elektronik di Politeknik Darussalam Palembang dengan menggunakan Open Journal System (OJS) yang dapat digunakan untuk publikasi artikel penelitian dosen-dosen di Politeknik Darussalam dan para peneliti di Bidang Pariwisata. Metode pengumpulan data menggunakan metode wawancara dengan pihak pengelola Jurnal Pariwisata Darussalam. Selain menggunakan metode wawancara, pengumpulan data juga dilakukan dengan melakukan observasi dengan cara mengamati OJS-OJS sejenis serta pengumpulan data dengan menggunakan studi pustaka. Metode pengembangan sistem yang digunakan untuk mengembangkan Jurnal Pariwisata Darussalam adalah metode rekayasa web yang merupakan gabungan dari aktifitas rekayasa perangkat lunak dan web publishing yang terdiri dari lima tahapan, yaitu Customer communication, planning, modeling, Construction, delivery dan feedback. Proses Construction meliputi pengaturan pada journal, website, workflow, distribution, users dan roles. Setelah melalui uji coba dari internal pengembang dan pihak Politeknik Darussalam yang terdiri dari dosen dan pihak pengelola jurnal, maka Jurnal Pariwisata resmi digunakan dan dapat di akses di https://ojs.politeknikdarussalam.ac.id/index.php/jpd yang dapat digunakan untuk publikasi artikel oleh dosen Politeknik Darussalam dan para peneliti pada bidang pariwisata.
\end{abstract}

Kata kunci : Open Journal System, Rekayasa web

Abstract - This study aims to develop an electronic journal-based Darussalam Tourism Journal at the Polytechnic Darussalam Palembang by using the Open Journal System (OJS) which can be used to publish research articles for lecturers at the Darussalam Polytechnic and researchers in the tourism sector. Interview with the manager of the Darussalam Tourism Journal is used as the data collection method. In addition, besides using the interview method, data collection was also carried out by making observations by observing similar OJS and also using literature studies. The system development method used to develop the Darussalam Tourism Journal is a web engineering method which is a combination of software engineering activities and web publishing which consists of five stages, namely customer communication, planning, modeling, construction, delivery and feedback. The Construction process includes settings for journals, websites, workflows, distributions, users and roles. After going through trials from internal developers and the Darussalam Polytechnic consisting of lecturers and journal managers, the Tourism Journal is officially used and can be accessed at https://ojs.politeknikdarussalam.ac.id/index.php/jpd which can be used for the publication of articles by Darussalam Polytechnic lecturers and researchers in the field of Tourism. 
Keywords: Open Journal System, Web Engineering

\section{PENDAHULUAN}

Tri Dharma Perguruan Tinggi merupakan tiga pilar dasar yang ada pada suatu Perguruan Tinggi. Berdasarkan Undangundang No,14 Tahun 2005 Pasal 60 tentang Guru dan Dosen dinyatakan bahwa Dosen memiliki kewajiban untuk melaksanakan Tri Dharma Perguruan Tinggi yang terdiri dari Pendidikan dan Pengajaran, Penelitian dan Pengembangan serta Pengabdian Kepada Masyarakat. (Tiyana, 2017). Banyak indikator yang digunakan untuk mengukur kompetensi dosen salah satu nya adalah kompetensi dosen pada proses belajar mengajar yang di evaluasi pada setiap semester oleh Sistem Penjamin Mutu Internal (SPMI), (Sukri, dkk, 2020). Selain di bidang pengajaran, bidang lainnya yang menjadi tolak ukur kinerja dosen dalam melaksanakan tri dharma adalah kuantitas dan kualitas publikasi karya ilmiah (Gunawan, DKK, 2020).

Hasil penelitian biasanya dipublikasikan pada jurnal ilmiah, baik jurnal ilmiah nasional ber ISSN (International Standard Serial Number) maupun jurnal ilmiah bereputasi baik di tingkat Nasional maupun Internasional (Parmin, 2017). Penilaian jurnal ilmiah di Indonesia melalui Akreditasi Jurnal Nasional (Arjuna) serta Science and Technology Index atau yang lebih dikenal dengan akronim SINTA, merupakan sebuah portal yang dikembangkan oleh Kementerian Riset dan Teknologi / Badan Riset dan Inovasi Nasional (Ristek Brin) Republik Indonesia pada tahun 2016 (Muriyatmoko, 2018)

Jurnal ilmiah telah banyak disediakan oleh Perguruan Tinggi maupun lembagalembaga penelitian. Sebagian besar jurnal ilmiah telah berbasis Jurnal Online. Salah satu sistem yang biasa digunakan untuk mengembangkan jurnal online adalah Open Journal System (OJS). OJS adalah salah satu standar untuk pengelolaan jurnal online yang bersifat terbuka baik di tingkat Nasional maupun Internasional.

Politeknik Darussalam merupakan salah satu perguruan tinggi swasta yang ada di kota Palembang. Politeknik Darussalam beralamat di Jalan Basuki Rahmat No.1608 E-F, Kecamatan Kemuning Palembang. Politeknik Darussalam mempunyai lima program studi yaitu Administrasi Bisnis Internasional, Administrasi Niaga, Akuntansi, Usaha Perjalanan Wisata, dan Paralegal. Politeknik Darussalam mempunyai banyak dosen tetap dan dosen luar biasa yang mempunyai latar belakang pendidikan yang berbeda sesuai dengan Program Studinya. Pada Program Studi Perjalanan Wisata terdapat enam Dosen Tetap dan empat Dosen Luar Biasa. Dosen-dosen pada Program Studi ini aktif melakukan penelitian tetapi kadang terkendala untuk melakukan publikasi hasil penelitiannya. Untuk Lembaga Penelitian dan Pengabdian Masyarakat (LPPM) Politeknik Darussalam berkeinginan membuat Jurnal Online yang dapat digunakan oleh dosen-dosen dari Program Studi Perjalanan Wisata dan juga penelitipeneliti di Bidang Pariwisata

\section{KAJIAN PUSTAKA DAN LANDASAN TEORI}

\section{Metode Pengumpulan Data}

Pada penelitian kegiatan penting yang harus dilakukan adalah pengumpulan data. Menurut Abubakar (2021) Teknik pengumpulan data dibagi menjadi tiga jenis, yaitu :

a) Wawancara atau Interview Wawancara atau interview adalah percakapan dua pihak atau lebih untuk tujuan tertentu. Wawancara terbagi menjadi dua kategori, yaitu wawancara terpimpin yang dilakukan dengan pedoman wawancara sehingga pertanyaan terarah dan 
wawancara tidak terpimpin, yaitu awancara yang dilakukan secara bebas namun masih pada seputar data yang diinginkan.

b) Observasi

Metode pengumpulan data dengan cara observasi, yaitu dimana peneliti melakukan pengamatan terhadap data atau objek yang diteliti. Pada metode observasi cara yang efektif adalah peneliti terlebih dahulu menyiapkan form yang akan diisi dengan hasil,pengamatan.

c) Angket atau Kuesioner

Angket atau kuesioner adalah daftar pertanyaan yang telah disiapkan oleh peneliti untuk diajukan kepada responden. Isi pertanyaan pada angket tersebut merupakan pertanyaan-pertanyaan dimana jawabannya akan digunakan untuk untuk menyelesaikan permasalahan penelitian yang sedang dilakukan. Secara garis besar angket dibedakan menjadi dua bagian yaitu angket terbuka dan angket tertutup. Angket terbuka adalah daftar pertanyaan yang jawabannya belum tersedia dan memberi kesempatan kepada responden untuk menjawab sesuai dengan pengetahuan dan kemampuannya. Sedangkang angket tertutup adalah daftar pertanyaan yang telah disediakan jawabannya. Responden hanya memilih salah satu dari jawabannya yang ada. Para peneliti sebagian besar memilih jenis angket tertutup karena mempunyai banyak kelebihan, diantaranya, mudah diolah dengan cara diberi kode dan skor, kelebihan lainnya waktu untuk pengisian angket relatif lebih cepat,

d) Dokumen

Dokumen adalah bahan tertulis atau video yang disiapkan karena permintaan. Teknik dokumentasi adalah cara mengumpulkan data melalui penelaahan sumber tertulis seperti buku, laporan, notulen rapat atau informasi lainnya yang dibutuhkan oleh peneliti.

\section{Metode Pengembangan Sistem}

Pada pengembangan sistem dikenal istilah Rekayasa Perangkat Lunak atau Software Engineering. Menurut Rizky(2011) dalam bukunya yang berjudul Konsep Dasar Rekayasa Perangkat Lunak , Rekayasa Perangkat Lunak adalah segala sesuatu yang berhubungan dengan proses pengembangan perangkat lunak sejak dari awal hingga tahapan implementasi serta pasca implementasi sehingga siklus hidup perangkat lunak dapat berlangsung secara efisien dan terukur. Pada pengembangan perangkat lunak banyak metode yang digunakan, salah satu metode yang biasa digunakan pengembang sistem adalah Metode Waterfall atau atau System Development Life Cycle (Siddik, Samsir, 2020). Secara garis besar metode ini menggunakan beberapa tahapan yaitu, analisis dan pengumpulan data, desain sistem, pengkodean, pengujian. Pada tahap analisis pengembangan biasanya melihat sistem yang berjalan saat ini sebagai dasar pengembangan sistem yang akan dibuat, selanjutnya mengumpulkan data-data yang digunakan untuk pengembangan sistem. Pada tahap desain dimulai dari desain data flow diagram, kemudian desain database, dan desain input output. Setelah selesai desain dilanjutkan pengkodean dengan bahasa pemrograman tertentu, dan akan dilakukan uji coba sebelum sistem diimplementasikan.

\section{Rekayasa Web}

Rekayasa web adalah metode pengembangan sistem untuk aplikasiaplikasi yang berbasis web. Tahapantahapan pada rekayasa web terbagi menjadi lima bagian (Hadinata, Udiriansyah, 2015), yaitu :

\section{a) Communication}

Communication atau komunikasi adalah tahapan pertama pada rekayasa web, pada tahapan ini pengembang dan tempat yang akan dikembangkan sistemnya menjalin komunikasi agar sistem yang dikembangkan sesuai dengan keinginan. Pada tahapan ini juga dilakukan pengumpulan data 
b) Planning

Planning atau perencanaan adalah tahapan perencanaan di sisi pengembang, pada tahapan ini pengembangan melakukan analisis kebutuhan dari perangkat keras, perangkat lunak, sumber daya manusia yang akan mengembangkan serta estimasi waktu untuk pengembangan.

c) Modeling

Pemodelan atau perancangan adalah tahapan merancang sistem yang akan dikembangkan, dari merancang diagram arsitektur, diagram aliran data, termasuk juga desain input dan output

d) Construction

Pada bagian ini dilakukan pengkodean program pada sistem yang akan dikembangkan. Setelah selesai pengkodean akan dilakukan uji coba terhadap sistem untuk memastikan sistem telah berjalan dengan baik.

e) Delivery and Feedback

Pada tahapan ini sistem di implementasikan dan di ui coba pada tempat nya. Sistem akan dicoba pada semua fitur yang ada, serta akan diberikan tanggapan untuk kesempurnaan sistem.

\section{Open Journal System}

Open Journal System (OJS) adalah salah satu Platform Jurnal Online yang di kembangkan oleh Public Knowledge Project (PKP) yang dirilis menggunakan lisensi GPU (General Public License) dan bersifat Open Source (Ridwan, 2019 ). Karena bersifat open source dan mempunyai banyak fitur-fitur yang tersedia maka sistem ini dapat dikembangkan oleh siapa saja untuk mengembangkan sesuai keinginan pengelola jurnal (Sumarno, Silitonga, 2021), selain itu juga jurnal berbasis OJS sangat kompatibel dengan search engine google, maka dengan demikian artikel penelitian yang dipublikasikan di jurnal online berbasis OJS akan terindeks dengan baik di Google Scholar.(Allo, 2020). Secara garis besar pada pengelolaan jurnal berbasis OJS terdapat enam tahapan utama, yaitu pengiriman naskah atau biasa dikenal dengan istilah submission article, selanjutnya adalah, proses review oleh reviewer yang biasanya di review oleh dua reviewer yang ahli di bidang nya. Setelah di review penulis akan melakukan proses editing berdasarkan catatan reviewer. Setelah beberapa kali proses review, maka admin OJS akan melakukan pengelolaan terbitan, publikasi, dan penerbitan jurnal edisi terbaru. (Arief, Handoko, 2018)

\section{METODE}

Penelitian ini termasuk ke dalam Research and Development yaitu penelitian dan pengembangan untuk membuat jurnal online dengan menggunakan OJS. Metode pengembangan sistem menggunakan Metode Rekayasa Web yang tahapantahapannya dapat dilihat pada gambar $1 \mathrm{di}$ bawah ini

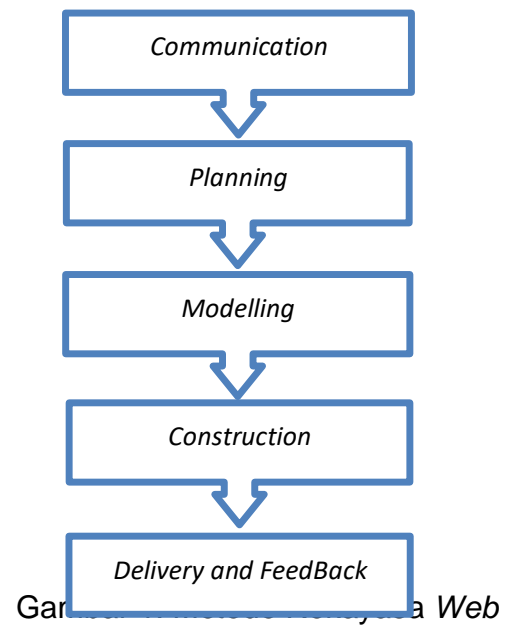

Metode rekayasa web menggabungkan metode waterfall atau System Development Life Cycle dengan teknologi berbasis web. Untuk lebih jelasnya tahapan-tahapan pada metode rekayasa web adalah sebagai berikut :

\section{Communication}

Sebelum memulai pengembangan yang bersifat teknis, langkah awal yang perlu dilakukan adalah menjalin komunikasi dengan pengguna yang dalam hal ini adalah Politeknik Darussalam. Komunikasi ini digunakan untuk mencapai hasil akhir yang sesuai dengan keinginan pengguna. Pada tahapan ini juga dilakukan pengumpulan 
data-data yang akan digunakan untuk mengembangkan Jurnal yang berbasis OJS. Pengumpulan data melalui wawancara (interview) dengan pihak editor jurnal Pariwisata Darussalam, hasil wawancara dicatat dan diketik pada laptop yang nanti data-data nya akan digunakan pada halamanhalaman OJS, Selain menggunakan metode wawancara, pengumpulan data juga dengan cara observasi. Penulis melakukan observasi pada OJS-OJS sejenis yang telah ada, penulis mengamati tampilan utama dan tampilan halaman-halaman yang biasa ada pada OJS. Selain itu juga untuk melengkapi kebutuhan data dan informasi penulis melakukan studi pustaka dari buku dan artikel penelitian tentang OJS.

2. Planning, setelah menjalin komunikasi dan pengumpulan data, tahapan selanjutnya adalah perencanaan meliputi kebutuhan perangkat keras , perangkat lunak, tim pengembang serta estimasi waktu yang dibutuhkan untuk pengembangan sistem

a. Perangkat keras yang digunakan pada pengembangan ini adalah Laptop dengan Spesifikasi Processor AMD A9 Core 2C 3G 3.0 GHz, RAM 4 GB dan Harddisk $500 \mathrm{~GB}$

b. Perangkat Lunak yang digunakan adalah XAMPP 7.3.3 sebagai web server lokal yang perangkat lunak untuk instalasi nya di download di https://www.apachefriends.org/dow nload.html, Untuk instalasi OJS penulis menggunakan Versi 3.3.0 6 yang di download di https://pkp.sfu.ca/ojs/ojs_download /

c. Untuk mengembangkan OJS Pariwisata Darussalam adalah penulis berdua

d. Estimasi waktu pengerjaan adalah 1 (satu) bulan, yaitu dari tanggal 12 April 2021 sampai dengan 12 Mei 2021

\section{Modeling}

Tahapan ini berfokus pada perancangan yang meliputi pemodelan dari urutan dari kegiatan proses dari OJS. Pemodelan menggunakan alur yang telah ada pada framework OJS..

4. Construction

Pada tahapan construction dilakukan pengkodean dan pengaturan di masingmasing halaman yang ada pada OJS sehingga menghasilkan tampilan yang menarik serta mudah untuk digunakan. Pada Framework OJS pengguna dapat melakukan pengaturan pada bagianbagian berikut ini :

a. Journal, bagian ini pengaturan meliputi nama jurnal, pengelola, beserta aturan-aturan yang ada pada jurnal

b. Website. Pada bagian ini pengembang dapat melakukan pengaturan pada empat bagian , yaitu bagian pertama adalah : Appearance yang mengatur tema tampilan, tipografi, warna, dan header. Bagian kedua adalah : Set up yang digunakan untuk pengaturan informasi, bahasa, Navigasi, Pengumuman, List, pernyataan privasi, tanggal dan jam. Bagian ketiga adalah : Plug in yang digunakan untuk menambahkan fitur-fitur yang ada pada OJS seperti metadata, block yang digunakan untuk membuat menu dan block pada OJS. Pada bagian keempat : static page yang digunakan untuk menampilkan halaman seperti dewan editor, reviewer, dan halaman-halaman informasi lainnya.

c. Workflow, bagian ini digunakan untuk pengaturan proses publikasi jurnal meliputi submission, review, publisher library dan email.

d. Distribution, pada bagian ini digunakan untuk pengaturan license, search indexing, payment, access, dan archiving

e. Users dan roles, bagian ini digunakan untuk pengaturan users, roles, dan site access option.

Pengaturan OJS dilakukan menggunakan dua tahap, yaitu pengaturan di server lokal dan pengaturan di server Politeknik 
Darussalam. Setelah selesai melakukan pengaturan-pengaturan sesuai dengan keinginan pemilik jurnal, proses selanjutnya pada permintaan untuk pengkodean dan pengaturan halaman, dilanjutkan dengan uji coba pada kegiatan construction adalah melakukan uji coba. Pada proses uji coba penulis akan melibatkan tenaga laboratorium dan mahasiswa STMIK Palcomtech.

5. Delivery and Feedback

Pada tahapan ini sistem atau OJS yang telah dikembangan pada server lokal dan di hosting ke server Politeknik Darussalam akan serah terima kepada pihak pengelola jurnal dan administrator jurnal Pariwisata Darussalam. OJS akan di uji coba secara keseluruhan baik dari pihak pengguna atau peneliti yang akan melakukan publikasi, pihak reviewer, dan juga admin yang mengelola Jurnal Pariwisata Darussalam. Jika ada masukan dari pihak-pihak terkait, maka penulis akan melakukan perbaikan. Setelah OJS dianggap telah memenuhi standar jurnal online, maka OJS telah siap untuk digunakan.

\section{HASIL DAN PEMBAHASAN}

Setelah melakukan komunikasi dengan pihak Politeknik Darussalam dan melakukan wawancara serta melakukan observasi pada OJS-OJS sejenis yang telah digunakan pada beberapa Perguruan Tinggi dan melengkapi data dengan studi pustaka. Selanjutnya penulis menyiapkan peralatan-peralatan yang digunakan untuk pengembangan. Untuk master server web lokal dan OJS penulis mengambil dari sumber resmi yaitu di https://www.apachefriends.org/download.h tml, Untuk instalasi OJS penulis menggunakan Versi $3.3 .0 \quad-6$ yang di download

https://pkp.sfu.ca/ojs/ojs_download/.

Setelah data, peralatan dan bahan lengkap maka dimulai instalasi dan pengaturan OJS. Instalasi dan pengaturan dimulai dari server lokal, baru kemudian di upload ke server Politeknik Darussalam untuk dilakukan penagturan lebih lanjut.
Pengaturan pertama dilakukan pada OJS dimulai dari pengaturan Journal yang dilakukan untuk memberikan informasi seputar nama jurnal, inisial, informasi penerbit, no ISSN atau E-ISSN, ringkasan dan deskripsi. Pada bagian ini ditambahkan informasi meliputi nama, no kontak, dan alamat email. Pengaturan pada bagian Journal ini dapat dilihat pada gambar 2 berikut ini

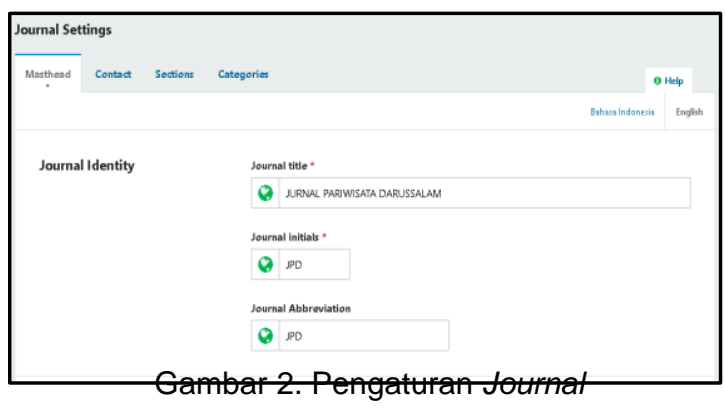

Setelah melakukan pengaturan pada bagian Journal, selanjutnya dilakukan pengaturan pada bagian website. Pengaturan pada website terbagi menjadi empat bagian, yaitu bagian Appearance atau tampilan yang meliputi tema, warna, huruf, dan header. Bagian kedua pada pengaturan website adalah setup yang digunakan untuk pengaturan bahasa, navigasi, pengumuman, list, pernyataan, serta pengaturan tanggal dan jam. Bagian ketiga pada pengaturan website adalah Plugin yang digunakan untuk menambahkan fitur-fitur yang ada pada OJS. Bagian terakhir pada pengaturan website adalah static pages yang digunakan untuk menambahkan halamanhalaman informasi yang digunakan pada OJS. Pada pengaturan disini pengembang dapat menambahkan halaman-halaman yang dibutuhkan melalui tombol Add Static Page. Pengaturan Website pada bagian static pages dapat dilihat pada gambar 3 berikut ini

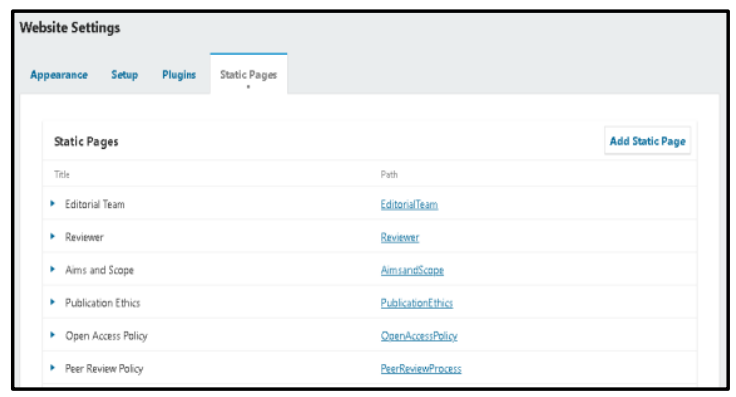


Gambar 3. Pengaturan Website

Setelah selesai pengaturan pada website, pengaturan selanjutnya adalah Pengaturan pada bagian Workflow. Pengaturan workflow digunakan untuk proses pengiriman artikel dari penulis artikel. Pengaturan workflow yang meliputi bagian submission, review, publisher library, dan email. Pada bagian submission pengaturan meliputi pengisian metadata, component, checklist, dan Author Guideline. Pengaturan workflow dapat dilihat pada gambar 4 berikut ini

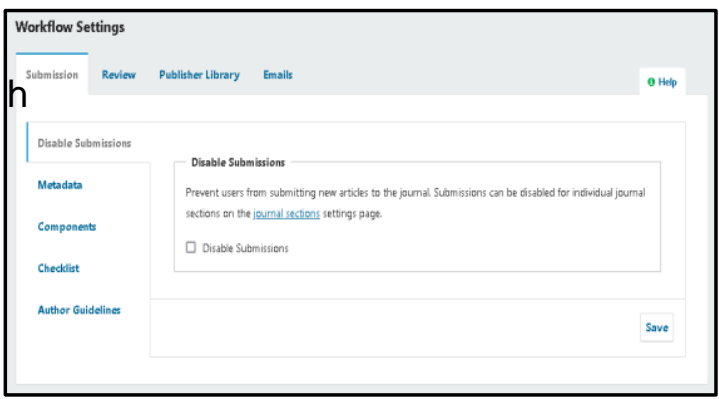

Gambar 4. Pengaturan Workflow

Setelah proses pengaturan workflow, proses pengaturan selanjutnya adalah dibagian distribution. Pada bagian ini akan diatur mengenai pengaturan license, search indexing, payment, access, dan archiving. Pengaturan bagian bagian distribution dapat dilihat pada gambar 5 berikut ini

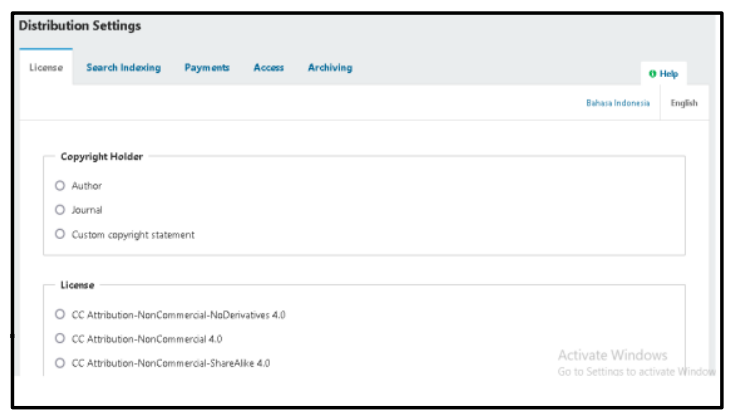

Gambar 5. Pengaturan Distribution

Pengaturan selanjutnya adalah yang berhubungan dengan pengguna OJS. Pengaturan dilakukan pada bagian user dan roles. Pengaturan ini digunakan untuk mengatur hak akses masing-masing pengguna OJS, seperti author, reviewer, journal editor, dan pengguna lainnya.

Pengaturan user dan roles dapat dilihat pada gambar 6 berikut ini

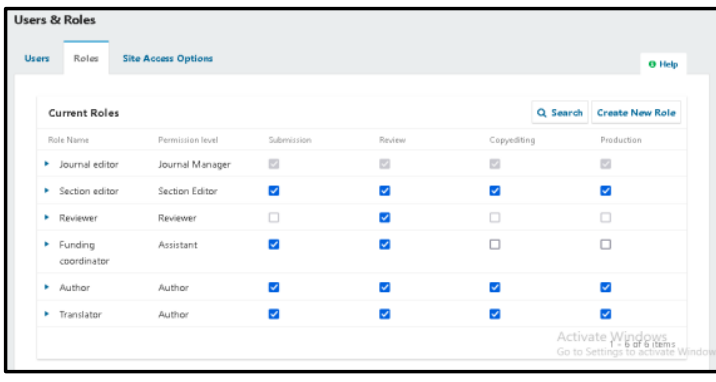

Gambar 6. Pengaturan User dan Role

$s$

Setelah selesai melakukan pengaturanpengaturan pada OJS. Tahapan berikut nya adalah uji coba OJS untuk memastikan semua halaman-halaman beserta fitur-fitur yang terdapat pada OJS berfungsi dengan baik. Proses uji coba terbagi menjadi dua tahapan, yaitu dari internal pengembang dan uji coba dari pihak Politeknik Darussalam, Pada proses uji coba yang dilakukan oleh Dosen-dosen Program Studi Perjalanan Pariwisata Politeknik Darussalam, dimulai dari proses membuat akun pada form register. Proses pembuatan akun digunakan untuk melakukan proses publikasi artikel. Proses membuat akun dengan mengisi formulir berupa nama, afiliasi, kota, e-mail, username. Penulisan username disini harus menggunakan huruf kecil. Setelah mengisikan user name, selanjutnya pengguna diminta mengisi , password dan konfirmasi password, Tampilan form register dapat dilihat pada seperti gambar 7 berikut ini

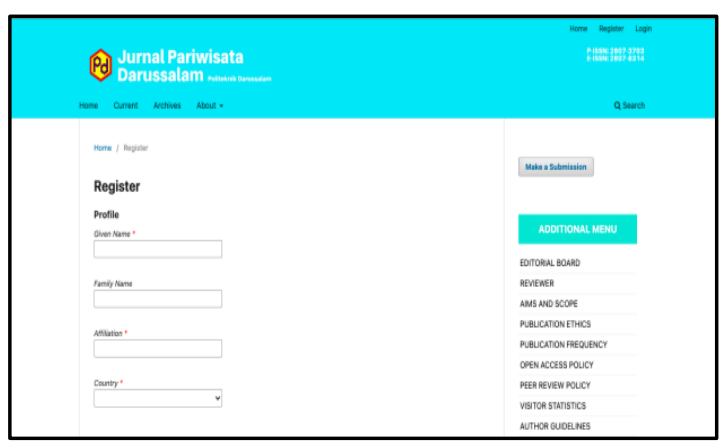

Gambar 7. Form Register

Setelah melakukan proses registrasi, pengguna dapat melakukan login ke dalam OJS, dan melanjutkan dengan mengunggah jurnal dengan memilih tombol 
"Make a Submission" dan memilih "Make a new submissions".

Langkah selanjutnya pengguna diminta untuk memilih bahasa dari jurnal yang ingin diunggah dan mencentang semua persyaratan yang dibutuhkan, seperti karya yang di upload adalah benar karya yang orisinil, pengguna menyetujui untuk menerima konfirmasi pemberitahuan melalui email dan lain sebagainya. Tampilan halaman ini dapat dilihat pada gambar 8 dibawah ini

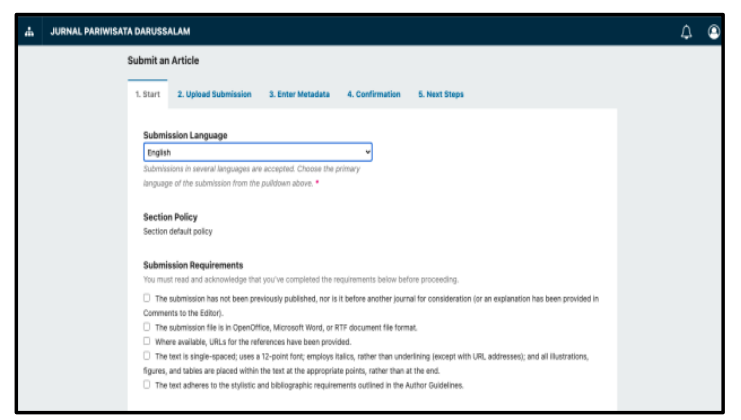

Gambar 8. Start Submission

Langkah selanjutnya pengguna dapat melakukan pengunggahan file jurnal ke dalam OJS, File artikel yang di unggah adalah berbentuk dokumen sehingga dapat memudahkan reviewer untuk memberikan catatan. Setelah selesai unggah artikel langkah selanjutnya adalah pengguna mengisikan metadata yang meliputi judul, abstrak, dan kata kunci. Setelah selesai pengisian metadata pengguna menekan tombol save and continue untuk ke proses selanjutnya, proses selanjutnya nya adalah menyelesaikan proses submission dengan cara memilih tab Confirmation dan pilih tombol "Finish Submission", seperti terlihat pada gambar 9 di bawah ini

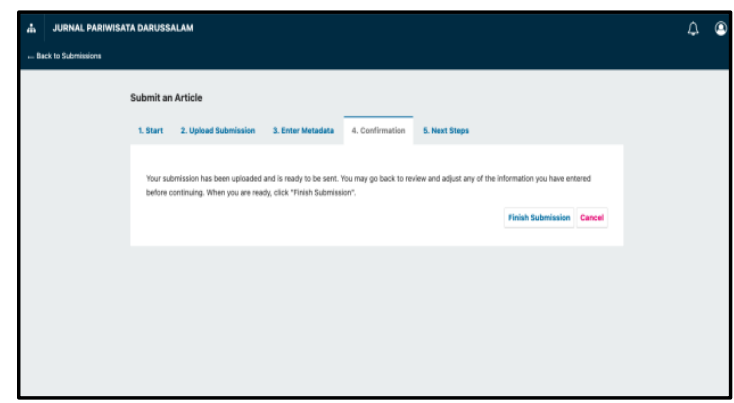

\section{Gambar 9. Finish Submission}

Setelah peserta melakukan tahap penyelesaian submisi jurnal, langkah selanjutnya peserta akan menerima notifikasi email bahwa jurnalnya telah berhasil diunggah. Langkah selanjutnya adalah peserta menunggu hasil dari review dari para reviewer, yang mana hasil dari review akan dikirim ke e-mail para peserta masing-masing sesuai dengan catatan dari para reviewer. Proses review dari reviewer bisa berulang sesuai dengan perbaikan yang ada. Pada tahap akhir apabila artikel sudah tidak ada lagi kesalahan, maka artikel akan diterbitkan pada edisi yang tersedia.

Setelah Proses uji coba selesai dan semua halaman dan fitur-fitur pada OJS sudah berjalan sesuai keinginan, maka OJS Pariwisata Darussalam telah siap digunakan. OJS Pariwisata Darussalam dapat diakses di halaman :https://ojs.politeknikdarussalam.ac.id/inde x.php/jpd , Tampilan halaman OJS Pariwisata Darussalam dapat dilihat pada gambar 10 berikut ini

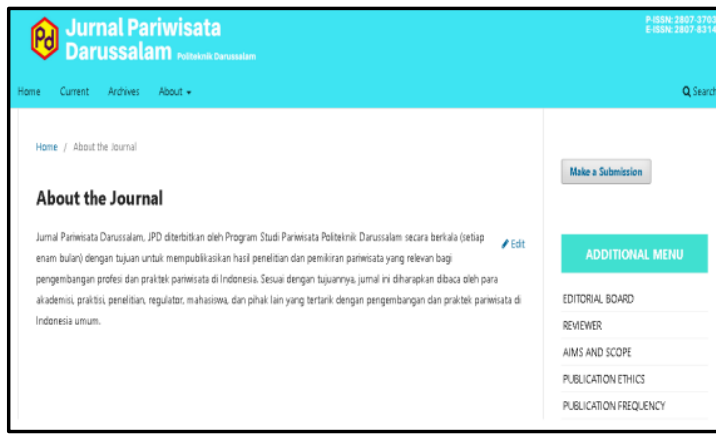

Gambar 10. Tampilan

OJS Pariwisata Darussalam

\section{KESIMPULAN}

Berdasarkan uraian pada bagian sebelumnya dapat disimpulkan Jurnal Elektronik Politeknik Darussalam dikembangan menggunakan metode rekayasa web dengan menggunakan Open Journal System (OJS) dari Public Knowledge Project yang dapat digunakan oleh dosen-dosen Politeknik Darussalam khususnya dosen dari Program Pariwisata 
serta Dosen dan penelitian di bidang Pariwisata dari berbagai Perguruan Tinggi dan Lembaga lainnya. OJS ini dapat diakses secara terbuka sehingga memudahkan pengguna atau peneliti untuk melakukan publikasi artikel ilmiah maupun mencari referensi penelitian di Bidang Pariwisata.

Untuk mendapatkan Fitur-fitur yang terbaik disarankan pengembang OJS selalu menggunakan versi terbaru serta menggunakan Bootstrap.css untuk membuat tampilan OJS lebih menarik.

\section{DAFTAR PUSTAKA}

Abubakar Rifa'l, 2021, Pengantar Metodologi Penelitian, Suka Press UIN Sunan Kalijaga, ISBN : 978-623-781625-6

Allo Pare Karmila, Ahmad Ismail Ode La., 2020. Google Scholar Metrics, Pengaruhnya Pada Jurnal IImiah, Jurnal IImu Perpustakaan, Informasi dan Kearsipan, ISSN : 2354-9629, DOI : 10.24252/kah.v8i1a10

Arief Ichwan, Handoko, (2018), Jurnal Online Dengan Open Journal System, Lembaga Pengembangan Teknologi Informasi dan Komunikasi (LPTIK) Universitas Andalas, ISBN : 978-602622-28-2

Gunawan. Dkk., (2020). Penyuluhan Tentang Peluang Dan Tantangan Penerapan Tri Dharma Perguruan Tinggi Di Era Revolusi 4.0, Jurnal Penelitian dan Pengabdian Masyarakat, ISSN : 2614-7947

Hadinata Novri, Udariansyah Devi, 2015, Implementasi Metode Web Engineering Dalam Perancangan Sistem Informasi Penerimaan Mahasiswa Baru dan Tes Online, Seminar Nasional Teknologi Informasi dan Aplikasinya, LPPM STIKI Malang

Muriyatmoko Dihin, (2018), Analisa Volume Terhadap Sitasi Menggunakan Regresi Linear Pada Jurnal Bereputasi Di Indonesia, Jurnal Simantec, ISSN : 2088-2130
Parmin, (2017), Analisis Penelitian IPA, Publikasi, dan Jurnal IImiah Bereputasi, Seminar Nasional Pendidikan Sains, Universitas Sebelas Maret Surakarta

Ridwan Muhammad, Rusdianto Sagita Denny, Ananta Tri Mahardika, (2019), Pengembangan Aplikasi Service Open Journal System (OJS) (Studi Kasus : Fasilkom UB), Jurnal Pengembangan Teknologi Informasi dan Ilmu Komputer, e-ISSN : 2548964X

Siddik Muhammad, Samsir, (2020), Rancang Bangun Sistem Informasi POS (POINT OF SALE) Untuk Kasir Menggunakan Konsep Bahasa Pemrograman Berorientasi Objek, JOISIE Journal Of Information System And Informatifc Engineering, ISSN : 2503-5304,

Sukri, Yulianti Wita, Tisnawati Liza, (2020), Sistem Monitoring dan Evaluasi Tri Dharma Perguruan Tinggi Sebagai Implementasi Penjamin Mutu Internal Dengan Laravel dan Rafid Application Development (RAD), JOISIE Journal Of Information System And Informatics Engineering, ISSN : 2503-5304,

Sumarno, Silitonga Farngky, (2021), Pelatihan Pembuatan dan Pengembangan OJS Muntaz dan AlMuharrik STIT. Muntaz Karimun, Jurnal Al-Muharrik Karimun, ISSN : 2772-5355

Triyana, I. G. N., (2017). Penjaminan Mutu Pendidikan Melalui Teknologi Informasi di Institut Hindu Dharma Negeri Denpasar, Jurnal Penjamin Mutu, e-ISSN : 2548-3110 